\title{
Critical Reviews in Microbiology
}

\section{Fungi in archives, libraries, and museums: a review on paper conservation and human health}

\section{Ana Catarina Pinheiro, Sílvia Oliveira Sequeira \& Maria Filomena Macedo}

To cite this article: Ana Catarina Pinheiro, Sílvia Oliveira Sequeira \& Maria Filomena Macedo (2019) Fungi in archives, libraries, and museums: a review on paper conservation and human health, Critical Reviews in Microbiology, 45:5-6, 686-700, DOI: 10.1080/1040841X.2019.1690420

To link to this article: https://doi.org/10.1080/1040841X.2019.1690420

View supplementary material \lceil

Published online: 09 Dec 2019.

Submit your article to this journal $₫$

LII Article views: 393

Q View related articles

View Crossmark data \lceil

Citing articles: 5 View citing articles $๘$ 


\title{
Fungi in archives, libraries, and museums: a review on paper conservation and human health
}

\author{
Ana Catarina Pinheiro ${ }^{a * \dagger}$ (D), Sílvia Oliveira Sequeira ${ }^{a, b *}$ (D) and Maria Filomena Macedo ${ }^{a, b}$ (D)

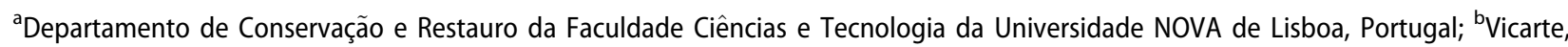 \\ Faculdade Ciências e Tecnologia da Universidade NOVA de Lisboa, Portugal
}

\begin{abstract}
The action of fungi on books, documents, maps, and works of art on paper can result in inestimable cultural losses. Plus, some of the fungi present in paper documents, surfaces and air from archives, libraries and museums are also a threat to human health. This work aims to review the literature on the most important and frequent microfungal populations found in paper-based collections all over the world, and correlate these data with human health risks. A total of 71 studies, dating between 1997 and 2018 were reviewed and organized. From 27 different countries, 207 fungal genera and 580 species were reported. Chaetomium sp. and Fusarium sp. were found to be special contaminants in the air of archives and have been associated with paper biodeterioration. The most common fungi reported (e.g. Penicillium, Aspergillus, and Alternaria species) have an impact on paper conservation but can also cause adverse human health effects. The most frequent fungal species retrieved from discoloured paper materials are discussed in greater detail. Considerations on methods of identification and quantification of fungal contamination are also presented. Finally, the authors acknowledge an urgent need for standardizing research in this area and further studies are proposed.
\end{abstract}

ARTICLE HISTORY

Received 19 March 2019

Revised 22 October 2019

Accepted 4 November 2019

Published online 20 November 2019

\section{KEYWORDS}

Fungi; archives; libraries; paper conservation; human health

\section{Introduction}

Important artistic works and documents are made of paper and, therefore, susceptible to chemical, physical, and biological damage. Biodeterioration of paper by fungi is one of the most important causes of damage occurring on library and archives collections (Figure 1). Some fungi involved in the biodeterioration of paper may also be dangerous to library/archival professionals and users as fungal metabolites can trigger allergic responses.

The last review on fungi isolated from library materials was performed by Zyska in 1997. In it, data were collected from very diverse origins as it was not just focussed on paper but on panoply of materials one can find in museums, archives, or libraries. Now, 22 years later, numerous researches regarding fungi on paper collections were made, new identification methods were applied and some fungal load limits, for paper conservation and human health, were proposed. Therefore, at this time several questions need to be answered: what is the present scenario in terms of fungal contamination in archives? Do air contamination studies relate to surface studies? Are the values similar between countries? What are the most common genera/species and can they induce damage to the collections and human health? Can we really talk about fungal load limits? Are the molecular biology protocols now being put to use bringing new light into the subject? And what are the major gaps in this research field?

This review intends to coordinate the data retrieved from isolated studies, dated from 1997 to 2018, and analyse it in order to progress towards answering the above questions.

\section{Methodology of the review process}

Literature research was performed to collect studies on the analysis of the mycoflora present in the air and surfaces of archives and libraries or discoloured paper from cultural heritage objects. Papers or book chapters were identified through searches using Science Direct,

CONTACT Sílvia Oliveira Sequeira sos11865@campus.fct.unl.pt $\Theta$ Departamento de Conservação e Restauro da Faculdade de Ciências e Tecnologia da Universidade NOVA de Lisboa, Portugal

*These authors should be considered joint first author.

${ }^{\dagger}$ Catarina Pinheiro is currently under a researcher contract at the Hercules Laboratory, Évora University (CEECIND/02598/2017), Cultural Heritage Protection Studies, Palácio do Vimioso, Largo Marquês de Marialva, 8, 7000-809 Évora.

(4) Supplemental data for this article can be accessed here.

(C) 2019 Informa UK Limited, trading as Taylor \& Francis Group 


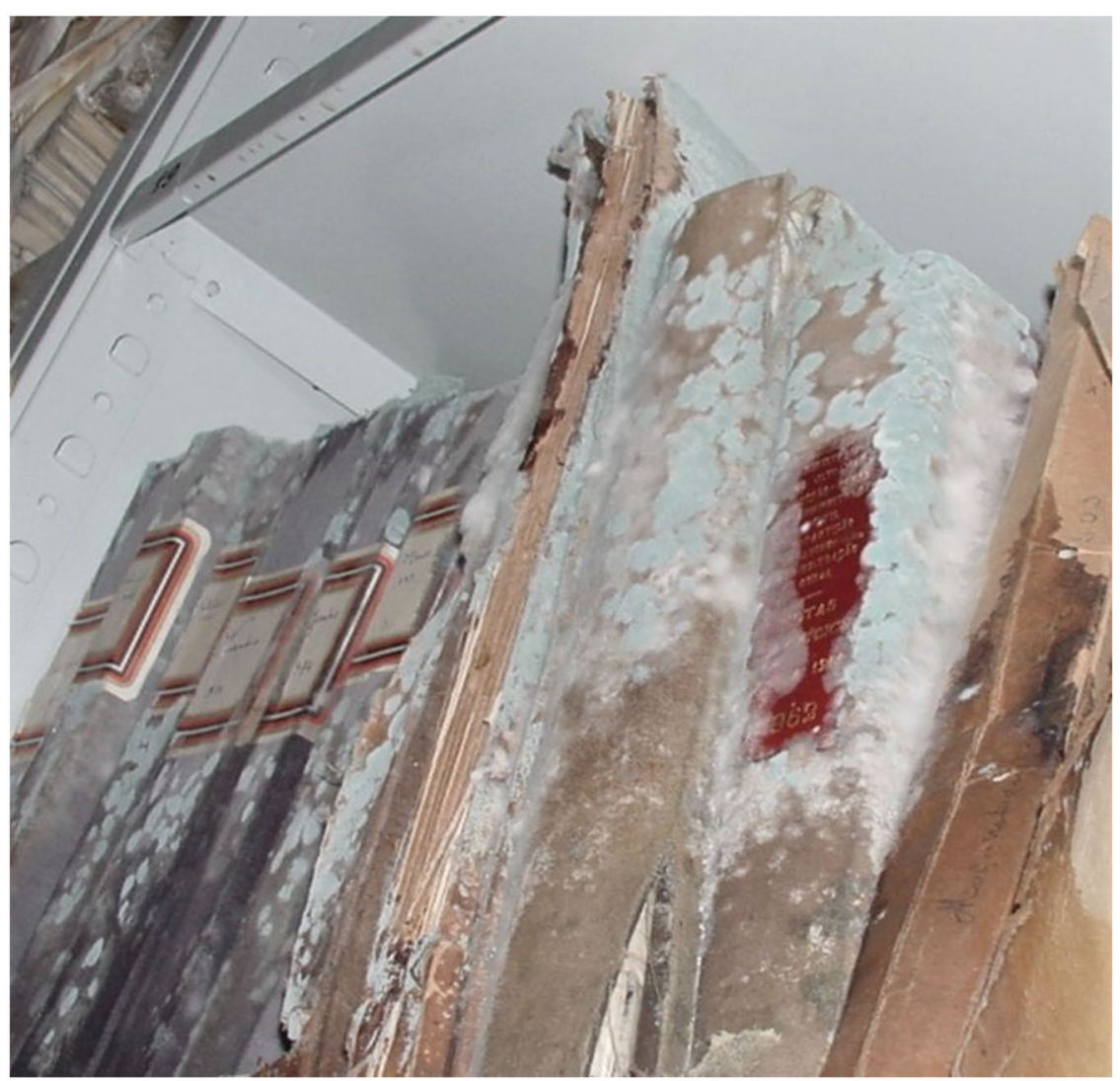

Figure 1. Fungal outbreak as a result of leaking water from the roof of a depository room (AHU-DGLAB, Portugal, 2005).

Scopus, ISI Web of Knowledge, Google Scholar, Google Books, and ResearchGate, with various combinations of the following search terms: fungi, microorganisms, mould, paper, archive, library, air, museum, cultural heritage, books, documents, health, and exposure. For air analysis, both active and passive methods were considered. The contamination of the surfaces considered the analysis of shelves, reading tables, bindings, and floors of the facilities holding paper-based collections.

The analysis of fungi from discoloured paper considered paper objects not only from libraries and archives but also from other cultural institutions holding different types of objects besides paper-based ones. Only samples taken from paper areas showing evidence of fungal colonization were considered, as the objective was to characterize the mycoflora eventually responsible for paper biodeterioration.

Only studies comprised between 1997 (after Zyska 1997) and 2018 were considered for this review, resulting in the compilation and analysis of 71 articles.

\section{Fungal species reported in archives and libraries}

Since Zyska (1997), a sharp increase in the number and quality of studies on biodeterioration of paper cultural heritage has been noted. Gathering nearly all the available data inevitably results in a vast display of information that is placed, with all necessary detail, as Supplementary Table S1. Table S1 presents the identified fungal species collected from air samples and surfaces in facilities holding paper collections, as well as from paper documents/artworks exhibiting fungal biodeterioration evidence, along with the countries where those studies were performed. The adopted nomenclature considered the species' current names according to the Mycobank Database (www.mycobank.org).

From Figure 2 one can spot the countries most committed to the study of fungal contamination in archives and libraries: Italy, Poland, Portugal, and Cuba present the highest number of published studies on the subject and they all have focussed on all the three sample types considered. However, given that the performed evaluations are very diverse regarding methodologies and sample treatment/analysis, it is not possible to infer directly on the intrinsic fungal flora diversity. This problem points to the need to find common ground and to establish experimental guidelines for the study of fungal contamination in archives.

In order to facilitate the analysis of the most commonly identified fungal species/genera in Table S1, 


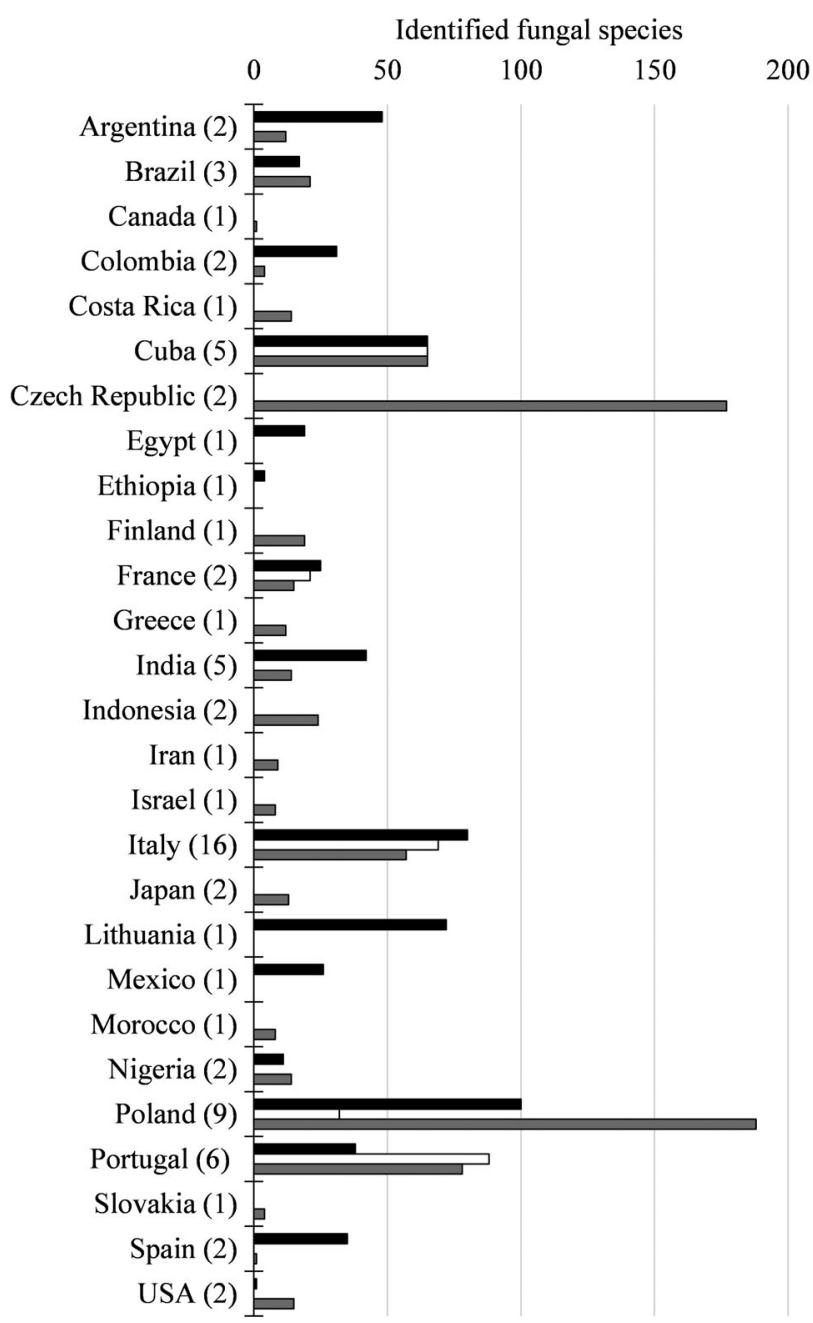

- Air samples $\square$ Surfaces $\square$ Discolored paper

Figure 2. The present review examined data from 27 different countries. In brackets are the number of studies analysed and also shown is the diversity encountered per country and per sample type (air, surfaces, and discoloured paper).

Figure 3 presents the fungi identified in more than three case studies.

\section{Air contamination - qualitative analysis}

The vast majority of environmental studies performed in the last 20 years focuses on the fungal population present in the air of the studied facilities. Cladosporium, Aspergillus, and Penicillium species are almost ubiquitous in air samples and can produce numerous conidia that can be easily dispersed by air (Abrusci et al. 2005). Many of the fungi most commonly encountered in the air of archives and libraries are capable of degrading cellulose: Aspergillus spp., Chaetomium spp., Trichoderma spp., and Penicillium spp. are some of them. Comparing with other environments, Chaetomium sp., Fusarium sp.,

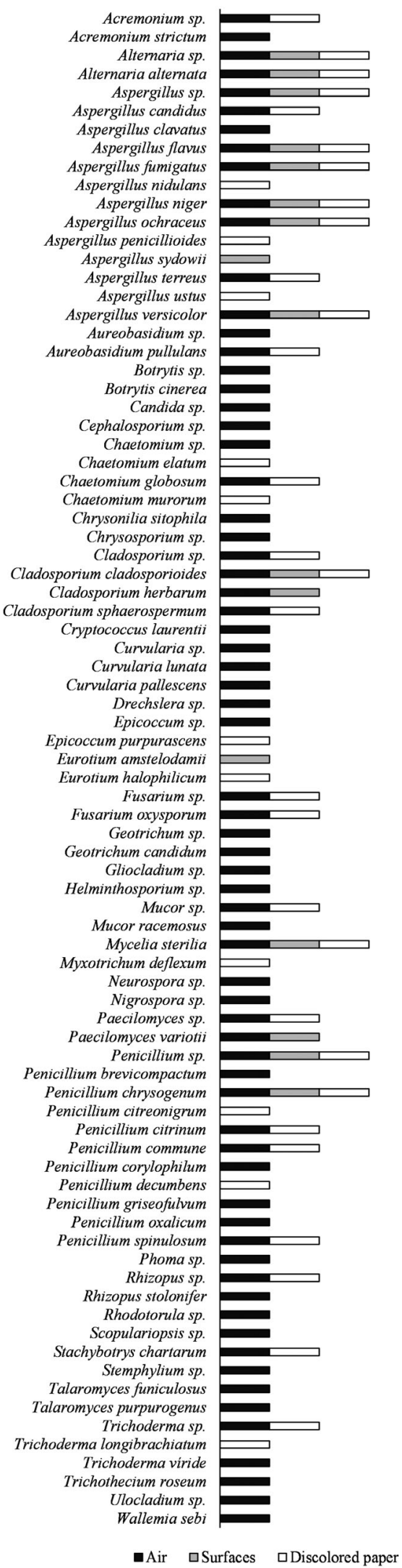

Figure 3. Fungal species isolated from air, surfaces or discoloured paper from the reviewed literature. Each bar (black, grey, or white) represents three or more studies from which these species were identified. 
and Geotrichum sp. were found to be special contaminants in the air of archives and the first two have been associated with paper biodeterioration (Caneva et al. 2003; Corte et al. 2003; Lourenço et al. 2005; da Silva et al. 2006). Trichoderma species are not considered common elsewhere and can be especially relevant in paper conservation as this genus is well known for its vast production of cellulases and hemicellulases (Pandey et al. 2015). Both Trichoderma viride and Trichoderma longibrachiatum were frequently identified in paper or air in the revised literature, as shown in Figure 3.

The fungi that most often cause allergic symptoms belong to the genera Alternaria, Cladosporium, Aspergillus, Candida, Penicillium, Mucor, Fusarium, and Rhizopus (Micalli et al. 2003). At least 600 species of fungi are in contact with humans and less than 50 are frequently identified and described in epidemiologic studies on indoor environments (Khan and Karuppayil 2012). Allergenicity tests conducted on an array of commonly encountered indoor fungi indicate that Aspergillus versicolour, Aspergillus niger, and Penicillium citrinum can induce allergic reactions (Khan et al. 2009). Potentially pathogenic/toxigenic species (Valentin 2007; NT-SCE-02 2009) Alternaria alternata, Aspergillus glaucus, A. niger, Aspergillus fumigatus, and A. versicolour, Chaetomium globosum, Cladosporium herbarum, Penicillium brevicompactum, and Stachybotrys atra have all been identified in air samples taken in archives and/ or libraries (Table S1). Valentin (2010) and the Portuguese Ordinance Law 353-A/2013 also consider Aspergillus flavus, Aspergillus ochraceus, and $A$ Aspergillus terreus, Trichoderma viride and Rhizopus nigricans potentially toxigenic, which are also present in the reviewed literature (Table S1).

In the work performed by Zielinska-Jankiewicz et al. (2008), 12 species were regarded as potentially pathogenic for humans: 8 of them displayed allergic properties and 11 displayed toxic properties. From the results obtained by their survey, Lugauskas and Kristaponis (2004) stress that the allergenic properties of the fungi detected in libraries, and their potential to produce, accumulate and release volatile toxic secondary metabolites into the library surroundings might pose a health risk to library workers. Both Chaetomium spp. and Stachybotrys spp. (present as most common in Figure 3) have produced various secondary metabolites in pure culture. C. globosum can produce chaetoglobosins and chetomin whereas other Chaetomium species can, on certain occasions, produce sterigmatocystin, a potent carcinogen. Stachybotrys chartarum can liberate trichothecenes and atranones, considered responsible for mycotoxicoses in humans (Bennett and Klich 2003).
Aspergillus species, abundant in the air samples presented in Table S1 and accounted as very frequent in archives around the world (see Figure 3 ) are also producers of mycotoxins. In vitro experiments show that metabolite and mycotoxins production is influenced by the media used, the incubation temperature, and the water activity (Nielsen 2003). This also explains why mycotoxins are not always detected even in the presence of mycotoxin-producing fungi. Moulds are likely to generate different metabolites when they grow on building materials and toxin production is affected by the biologic neighbours in mixed cultures (Nielsen 2003). Secondary metabolites and mycotoxins are species-specific which makes it very important to identify isolates to the species level. Also, mixtures of metabolites can see their effects added and potentiated (Nielsen 2003).

\section{Fungi retrieved from surfaces and its relevance in fungal contamination studies}

Very few studies present an evaluation of the surfaces where books and documents are actually kept and of the bindings that come in contact with the staff's/readers' hands. The studies performed in these settings, which are both quantitative and qualitative, are referred to in Table S1, third column - Isolation from surfaces (e.g. shelves, reading tables, and bindings).

As already mentioned, the last formal review regarding fungi in archives and libraries, performed by Zyska (1997), recollects data from very diverse origins. In fact, it is not just focussed on books but on panoply of materials one can find in museums, archives, or libraries. It does have the great advantage of presenting data from both air and surface samples which can be essential to truly know the fungal communities present in those locations. Some spores, given their characteristics, tend to aggregate and are not easily airborne which makes it difficult to find them in air samples although they can be present in the environment (Duchaine and Mériaux 2001). This could be deemed of lesser importance if this was not the case for Stachybotrys chartarum, the fungi most associated with Sick Building Syndrome (Bennett and Klich 2003). In the archival settings analysed in this review, this particular fungus can be considered common and is found in both the air and deteriorated paper samples (see Figure 3).

Sampling surfaces is also the best choice when looking for dermatophytes. These are fungi capable of degrading keratin. None of the three genera (Micros Porum, Trichophyton, and Epidermophyton) was found in 


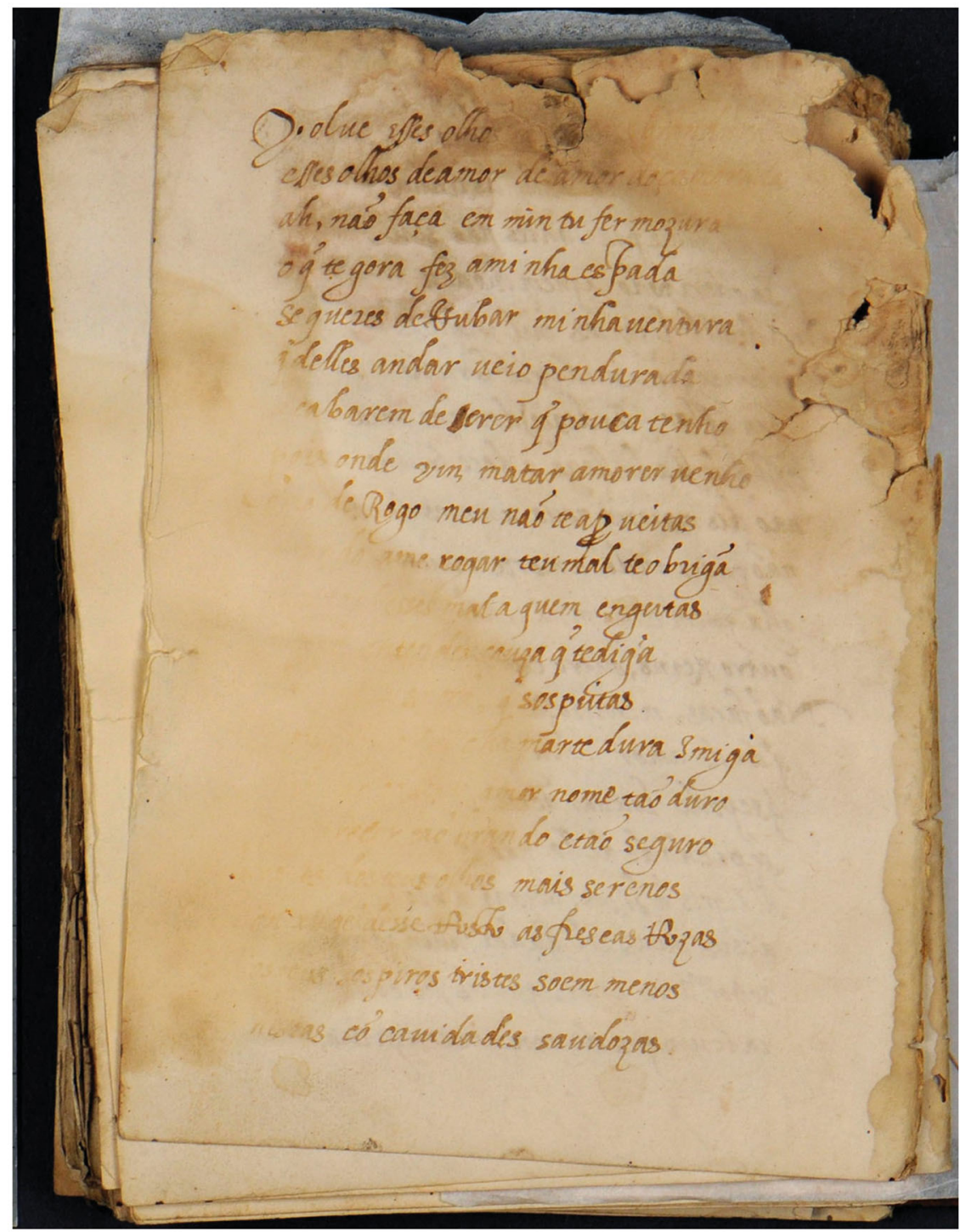

Figure 4. Detail of manuscript song book (sixteenth century, private collection) showing fungal biodeterioration.

previous studies, but Trichophyton rubrum and other keratinophilic fungi were isolated in a University library (Jain 2000). It is important for library and archival workers and users to be aware of this problem so that adequate care is taken when handling these contaminated surfaces.

Also Valentin (2007) quantitatively compared air and surface analyses and concluded that cellulose objects require longer exposure time in an improved climate to achieve a significant decrease in microbial growth. This adds to the importance of surface sampling cellulosic materials as these are a more reliable measuring tool in the event of altered environmental conditions.

Of the few studies performed on the analysis of surfaces (Table S1, third column), in Maggi et al. (2000) the most represented genera were Aspergillus (A. fumigatus included), Cladosporium sp., Penicillium sp., Chaetomium sp., and Alternaria sp. An average of 10 colony forming units (CFU) was determined per sampled area $\left(24 \mathrm{~cm}^{2}\right)$ $\left(\approx 4000 \mathrm{CFU} / \mathrm{m}^{2}\right)$. The study performed by ZielinskaJankiewicz et al. (2008) included both air and surface samples. Cladosporium and Penicillium were the most prevalent genera and the contamination levels were 800-1000 CFU $/ \mathrm{m}^{2}$. At the Jasna Góra monastery library, Harkawy et al. (2011) found the maximum concentration obtained per surfaced area to be $10000 \mathrm{CFU} / \mathrm{m}^{2}$. Levels such as the mentioned $10000 \mathrm{CFU} / \mathrm{m}^{2}$ were also found (and crossed) in Pinheiro (2014). In both Harkawy et al. (2011) and Zielinska-Jankiewicz et al. (2008), air samples resulted in a higher fungal diversity than surface samples, but in Pinheiro (Pinheiro 2014; Pinheiro 2015) surface samples presented a more diverse array of fungal genera/species than the one obtained in air samples. This result is in accordance to other settings (gymnasiums, elderly care centres, for instance) where the number of different species/genera in surfaces 


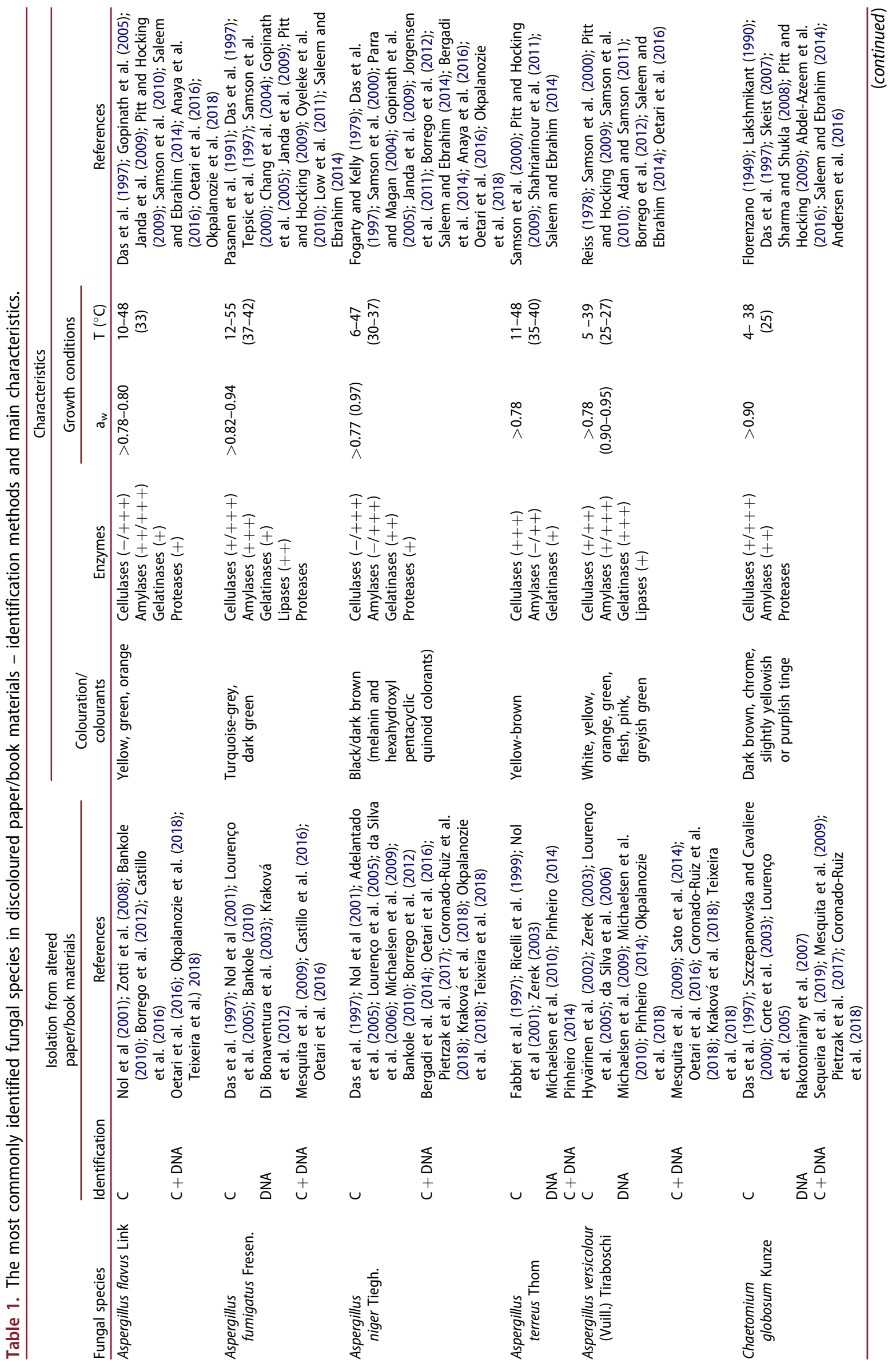




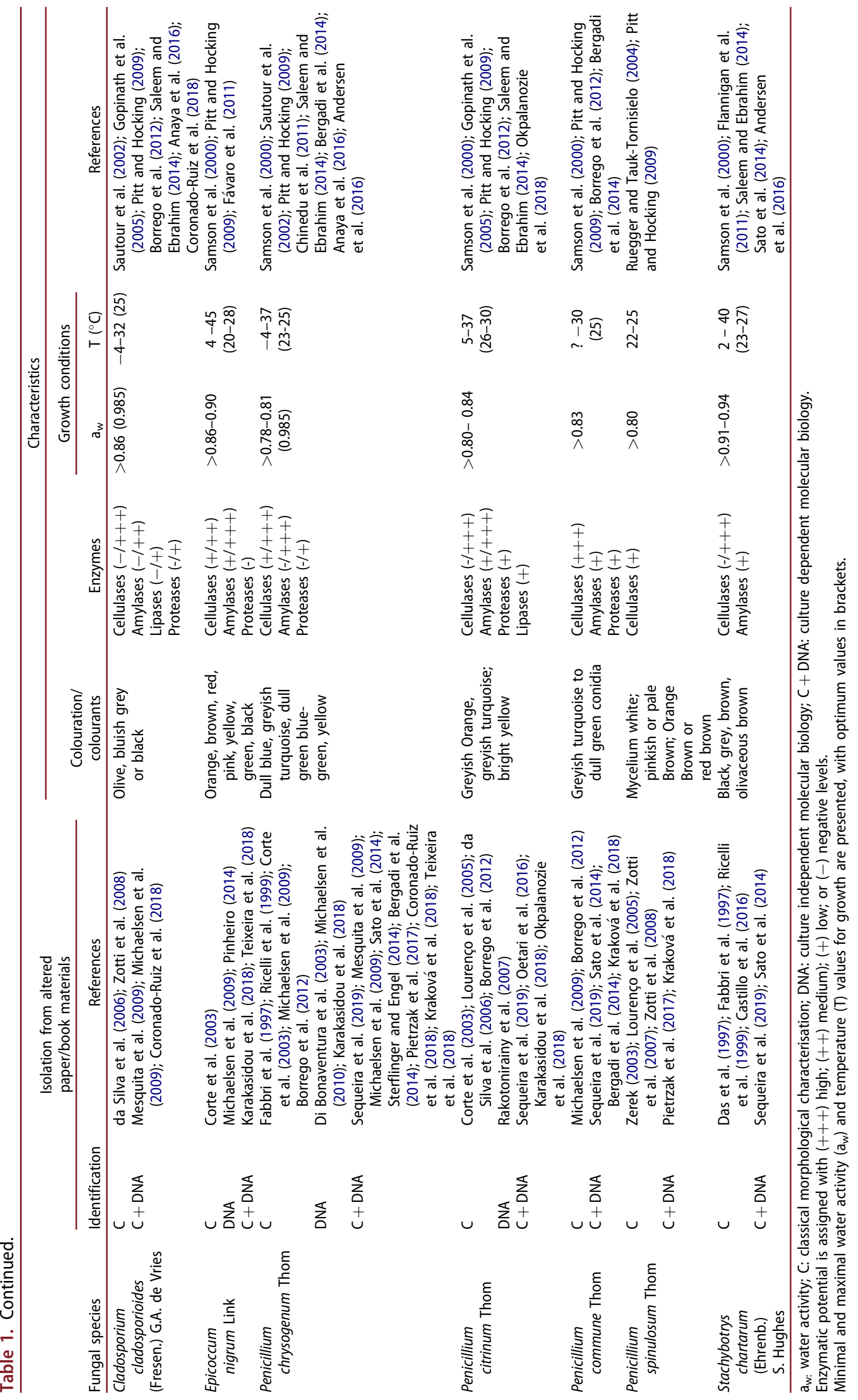


doubles the one found in air samples (Viegas et al. 2011; Viegas et al. 2014). The level of contamination is naturally related to dust and organic matter accumulation and one can argue that this can be prevented with maintenance. However, because archives and libraries are usually large premises with little room (and staff) to spare, proper maintenance can be a daunting task to perform regularly. Having this in consideration it is probably important to consider the use of personal protection when working in situ.

\section{Fungi retrieved from discoloured paper - more than suspects?}

Fungi are considered serious degrading agents of paper documents and works of art (Fabbri et al. 1997). Several studies have focussed on the effects fungi can have on our written heritage which can include pigment's and ink's discolouration (Florian and Manning 2000; Pinzari et al. 2006; Mesquita et al. 2009), chemical deterioration (Canhoto et al. 2004; Pinzari et al. 2010), formation of coloured stains, including foxing (Szczepanowska and Cavaliere 2003), and also physical and mechanical stress (Ponce-Jimenez et al. 2002; Caneva et al. 2003; Sterflinger 2010) (Figure 4). Some fungi can produce cellulolytic enzymes which break the cellulose polymer into smaller units, weakening the paper structure (Zyska 2002; Adamo et al. 2003; da Silva et al. 2006). Also, acidic metabolites can be excreted by these microorganisms, promoting acid hydrolysis in the paper fibres (Ponce-Jimenez et al. 2002). The release of all these extracellular enzymes and/or pigments acts chemically on the substrate.

The correlation between a given change in a document (a stain, for instance) and the presence of a fungal species has been the subject of several studies (Table $\mathrm{S} 1$, last column). Most of these studies have achieved a positive identification, but the doubt remains on many of them as to whether the identified fungus is the actual culprit for the (usually chromatic) alteration. It is also important to notice that only the most recent studies make use of molecular biology protocols for fungal identification, the majority of them in association with conventional culturing methods.

Apart from the cases where visible colonies are noticed, most of the damage associated with fungal causes appears in the form of chromatic changes in the paper. This effect may last long after the fungus has been active. From discoloured samples, with no visible fungal development, fungal growth is usually very difficultly attained and molecular biology protocols play a pivotal role in determining the possible culprit.
Due to their importance in paper conservation/restoration, the most frequently identified fungal species (identified to the species level and present in more than five studies) from discoloured paper and/or book materials taken from Table S1 are presented in greater detail in Table 1.

All these frequently identified fungi possess cellulolytic activity with varying degrees depending on the species and strain (Table 1). Besides cellulases, most species produce other exoenzymes that degrade paper composing or binding materials, like amylases (starch decomposition) and proteases (gelatin or leather decomposition). Also, they can excrete coloured metabolites with several different hues, having the potential to disfigure the documents and artworks they dwell in. The great majority of these fungal species are already able to develop at water activity levels near 0.80 , which qualifies them as xerotolerants. Regarding temperature, the optimum growth levels are circa $20-25^{\circ} \mathrm{C}$, a common interval for human comfort in libraries, archives and museums.

Fungi can excrete acidic compounds to alter the $\mathrm{pH}$ of the substrate according to their development needs. Fungal growth of species such as Aspergillus niger, $A$. terreus, A. ustus, and A. versicolour, Cladosporium cladosporioides, Penicillium chrysogenum, $P$. citrinum, and $P$. commune have shown the ability to greatly decrease the $\mathrm{pH}$ (up to $4 \mathrm{pH}$ units) of saline solutions initially buffered to $\mathrm{pH} 7$ (Borrego et al. 2012). A. niger is also capable of reducing a $\mathrm{pH} 8$ buffered iron gall ink growth medium to $\mathrm{pH} 1.7$ (Messner et al. 1988). This reveals a significant production of acidic metabolites by the most common fungal species found on paper materials. As paper is highly susceptible to acidic hydrolysis, such acid production represents an important biodeterioration potential. Sequeira et al. (2017) show the acidification and severe loss of folding endurance caused by the metabolites left by $A$. niger on paper in the long term.

Table 1 also highlights the methods used to achieve the identification of the deterioration potential culprits. We can see an increasing trend towards the use of molecular biology identification methods on the most recent studies where culture-dependent DNA analysis is the most used methodology.

Fungi like Chaetomium murorum, Myxotrichum deflexum, and Trichoderma longibrachiatum (and these are just the ones mentioned as most common) have only been identified in these sometimes very challenging samples through molecular biology (Table S1). However, the introduction of DNA analyses has also brought some problems in terms of data handling and 
processing. A joint collaboration was proposed by Katja Sterflinger and working groups at the IBBS Meetings in Manchester and Coimbra (Sterflinger et al. 2018), as recent advances in the identification methods (such as Next Generation Sequencing) have come to add (too much?) information and it is important that we do not lose focus on what is important for conservation: what is causing the problem, what are the deterioration mechanisms and how do we prevent and, ideally, revert them. Although still in a very incipient phase, the joint collaboration is aimed at defining gold-standard procedures (from collection to data analysis) in order to be able to advance in the understanding of biodeterioration. A database of the most commonly encountered microorganisms on cultural heritage damaged artefacts is the first step in this endeavour, and this review - on the very specific setting of archives and paper collections - could be an important contribution to this initial stage.

\section{Impact of fungal load on human health and paper preservation. Can it be assessed?}

Some fungi involved in the deterioration of paper may also be dangerous to library/archival professionals and users (Bennett and Klich 2003; Mesquita et al. 2009). Fungal spores can cause allergic skin and respiratory symptoms that may appear continuously or with seasonal rhythm. Skin contact with mould-infested substrates and inhalation of spore-borne toxins are also important sources of exposure (Bennett and Klich 2003). Mycotoxins, even in low concentrations, cause gastrointestinal disorders, damages to the haemopoietic and genital system, and non-specific symptoms (asthenia and nausea) similar to those connected with sick building syndrome (Micalli et al. 2003). According to some authors, the most common malaises reported by staff working in libraries, archives, or book containing premises are dermatitis, rhinitis, allergies, and asthma (Valentin 2007). During the last 20 years, very few studies evaluated the health risk resulting from exposure to this particular environment or from the use of paper materials. Wiszniewska et al. (2009), concluded that $30 \%$ of museum employees were sensitized to at least one of the fungal allergens tested and that the prevalence of allergic symptoms among the subjects was relatively high and frequently related to specific sensitization. The most frequent symptoms reported by the examined subjects were: conjunctivitis (68.5\%), rhinitis (66\%), skin symptoms (54\%), chronic cough (26\%), and dyspnoea (28\%). These symptoms are often related to the fungal load present in the air of the facilities holding paper-based collections. However, quantitative analysis of fungal load in the air of archives and libraries was performed by just a few authors (Table 2).

The mentioned studies used the impact method (air suction and immediate impact on an agar Petri dish) with contamination determined as $\mathrm{CFU} / \mathrm{m}^{3}$, but other methods and data presentations are possible, sometimes with completely different results (Molina-Veloso and Borrego-Alonso 2017). Such non-volumetric air sampling methods should only be used as preliminary or when only qualitative information is sought (Samson et al. 2000).

Some of the available proposals regarding fungal load indoor air limits (considering multiple building types) for health-risk are presented in Table 3. When considering human health, the data obtained from the air contamination studies presented in Table 2 reveals higher than recommended values by most of the existing guidelines on indoor air quality (Table 3 ). Despite the fact that environments containing fungal counts between 1 and $1000 \mathrm{CFU} / \mathrm{m}^{3}$ are considered low contaminated environments (according to (Nevailanen and Hyvarynen 2015)) one must take into account the fact that "total" levels of airborne microbial particles are normally between 10 and 100 times higher when using other than culture-based evaluation methods (Lignell et al. 2008; Nevailanen and Hyvarynen 2015) and this is probably the cause why, even in low mould-contaminated indoor settings, there are occupational diseases such as asthma, fungal allergy, hypersensitivity pneumonitis, and other health outcomes (Nevailanen and Hyvarynen 2015).

Table 2. Fungal contamination in indoor air determined for archives and libraries in different countries, analysed by the impact method.

\begin{tabular}{lll}
\hline Fungal concentration $\left(\mathrm{CFU} / \mathrm{m}^{3}\right)$ & \multicolumn{1}{c}{ Archive or library } & \multicolumn{1}{c}{ References } \\
\hline From 100 to 500 & Library of the Lithuanian Academy; Lithuania & Lugauskas and Krikstaponis (2004) \\
From 300 to 800 & $\begin{array}{l}\text { Martynas Mažvydas National Library of } \\
\text { Lithuania, Lithuania }\end{array}$ & Lugauskas and Krikstaponis (2004) \\
& Library and Archive Storage, Poland & Zielińska-Jankiewicz et al. (2008) \\
Average values between 180 and 2300 & Historical Archive of Ca' Granda; Italy & Cappitelli et al. (2009) \\
From 200 to circa 1500 & Arquivo Distrital de Évora; Arquivo Histórico & Pinheiro (2014); Pinheiro (2015) \\
From 2 to 200 & Ultramarino; Instituto de Habitação e & \\
& Reabilitação Urbana; Torre do Tombo & Molina-Veloso and Borrego-Alonso (2017) \\
\hline
\end{tabular}


Table 3. Fungal load indoor air limits for conservation and health-risk proposed by distinct authors in different countries and organisations.

\begin{tabular}{|c|c|c|}
\hline Fungal load limits and guidelines for Human Health (CFU $/ \mathrm{m}^{3}$ ) & & References \\
\hline $\begin{array}{l}>100 \text { is a sign of internal contamination } \\
<150 \\
<200 \\
<500 \\
2000-\text { very high contamination and a health threat } \\
<25-\text { Very low contamination } \\
25-100-\text { Low contamination } \\
100-500-\text { Intermediate contamination } \\
500-2000-\text { High contamination } \\
>2000 \text { Very high contamination }\end{array}$ & & $\begin{array}{l}\text { Ohgke et al. (1987); Hurts et al. (1997) } \\
\text { World Health Organisation } \\
\text { (Goyer et al. 2001) } \\
\text { Yang et al. (1993); Etkin (1994) } \\
\text { Reynolds et al. (1990) } \\
\text { Klánová (2000); Zielińska-Jankiewicz et al. (2008) } \\
\text { Hayleeyesus and Manaye (2014) }\end{array}$ \\
\hline Fungal load limits and guidelines for Conservation (CFU $/ \mathrm{m}^{3}$ ) & Country & References \\
\hline $\begin{array}{l}100 \\
120 \\
150 \\
200 \\
50 \text { for particular species } \\
150 \text { for a mixture of several species } \\
500 \text { for common airborne fungal contaminants } \\
0-25 \text { no expected problems; } \\
25-100 \text { possible presence of source, further testing needed; } \\
100-1000 \text { source present } \\
>1000 \text { active mould growth }\end{array}$ & $\begin{array}{l}\text { Netherlands (The Dutch } \\
\text { National Archives) }\end{array}$ & $\begin{array}{l}\text { Capderou and Flieder (1999) } \\
\text { Parchas (2009) } \\
\text { MIBAC (2001) } \\
\text { Karbowska-Berent et al. (2011) } \\
\text { Cieplik, } 1997 \text { (in Harkawy et al. (2011)) }\end{array}$ \\
\hline
\end{tabular}

High-level exposure to airborne viable fungi $\left(10^{6}\right.$ CFUs $/ \mathrm{m}^{3}$ ) was determined as the cause in a case of organic dust toxic syndrome in a museum staff handling mouldy books (Kolstad et al. 2002). According to Zielińska-Jankiewicz et al. (2008), some of the archive workers who participated in a survey conducted by Schata in 1995 reported various skin, eye, and respiratory symptoms which could have been associated with occupational exposure to moulds. It was estimated that about one-third of archive workers might have developed an allergy to moulds, which is about twice as high as in the general population. The workers taking part in the survey performed by Krake et al. in 1999 (ZielińskaJankiewicz et al. 2008), reported respiratory and sinusrelated symptoms which could have been associated with workplace exposure to moulds. In that study, mycological microflora belonging mostly to the Penicillium, Cladosporium, Aspergillus, Alternaria, and Tritirachium genera was detected in levels that ranged from 200 to $450 \mathrm{CFU} / \mathrm{m}^{3}$, depending on the facility, but for the Tritirachium species levels of approximately $800 \mathrm{CFU} / \mathrm{m}^{3}$ were measured.

Attempts have been made to determine the minimum amounts of CFU necessary to induce a negative reaction. This has not been an easy task since individual's variability alone is enough to impair the result from exposure to a given fungus or amount of fungi. Healthrisk levels suggested in the literature vary greatly from author to author and throughout the years. Being a much more recent discipline, no globally accepted international standard for paper conservation has yet been established (Cappitelli et al. 2010), either regarding the species or the number of fungi that can be considered dangerous when present in an archival environment. However, some countries have designed their own national guidelines and some countries have set them informally (Brokerhof et al. 2007; Harkawy et al. 2011).

Table 3 also presents the guidelines proposed for fungal load in distinct countries for paper conservation. All the studies presented in Table 2 indicate contaminated environments, according to the lowest level established by the Dutch National Archives guidelines (Table 3).

The measured $\mathrm{CFU} / \mathrm{m}^{3}$ variation is very high between countries (Table 2), within the same country and within the same facility at different seasons. Given this variability and the specificity of different fungal species regarding their toxic and deteriorating potential, it is probably too difficult (not to say misleading) to define an international maximum value of fungal load for conservation, instead, these values should be kept as low as possible. Studying the features of outside air, the least contaminated location and comparing them with the locations depicting a higher value should be a valuable aid in adopting the necessary practices to reduce fungal contamination. Periodic assessments, as well as a qualitative characterization of the fungal 
communities present, is also extremely important as it allows early detection of a shift in population - either in terms of the species or present amounts. Periodic surface analysis - and determining a desirable contamination level (after regular cleaning, for instance) - can also help determine whether or not to increase maintenance efforts.

The proposed values for maximum loads of fungi presented in Table 3 can be quite varied, do not depend on the fungal species, and the reasons behind a given value are not always well explained. Geographic differences should also be considered since a country's climatic characteristics are intimately related to the fungal flora. As in other settings, there are no proposed limits for surface contamination $\left(\mathrm{CFU} / \mathrm{m}^{2}\right)$. It would be of great interest to determine these limits since it is the surface of books and their condition that we intend to see preserved. As happens with the limits proposed for human health, the theoretical and experimental bases for the proposed numbers are sometimes difficult to ascertain. The extreme variability in the mentioned values may also be interpreted as a pointer to the need for identifying the species present in a given environment.

\section{Conclusions}

This review gathers studies from across the globe, showing us the fungal communities encountered so far in samples taken from altered paper samples, surfaces, and in the air of archives and libraries. A high number of different species were identified for the following genera: Penicillium (61 species), Aspergillus (44 species), Cladosporium (19 species), Chaetomium (16 species), and Trichoderma (11 species).

The most common genera found in the air of archives resemble the outdoor fungal flora as well as common contaminants of other unrelated settings. However, fungi like Fusarium sp., Chaetomium sp., and Geotrichum sp. display higher than usual frequencies in the air from archives and libraries. Many of the fungi most commonly encountered inside these places are capable of degrading cellulose. When obtained fungal loads are displayed against the existing guidelines and guideline proposals, some sampled locations cross the highest level defined by the Dutch Guidelines, of $1000 \mathrm{CFU} / \mathrm{m}^{3}$. The disparity obtained on $\mathrm{CFU} / \mathrm{m}^{3}$ reinforces the need for further studies, namely the identification of the contaminating species, a measure of great importance not only for conservation purposes but also for human health concerns.
The air is not the only source of contamination. Surfaces are a resting site for fungal particles and often translate a wider picture in terms of fungal diversity. The study of these surfaces reveals the communities from which the biodeterioration agents emerge and thrive. Another type of surface considered in this review is the specific location where discolouration occurred and fungal biodeterioration is considered as a possible cause. For the most relevant fungal elements encountered in these specific locations, the methods of identification are also presented.

Regarding fungal identification, determining the microfungal agents responsible for paper biodeterioration has not been an easy task and has led to confusion and never-ending lists of possible culprits. The identification of a fungal genus or species on a document does not necessarily mean this fungus is the actual cause. To overcome this issue, evidence suggests the need for various and simultaneous methods to be employed since no single method developed so far gives us the full picture. Also, to be able to make the most out of every research project, to achieve comparable results and truly advance in the field, a joint effort is being made to define standard operating procedures and create an environment where different backgrounds and expertise come together to address this important and complex field. Several initial measures are to be taken. The first step is the creation and management of a databank with information related to what, where and how microorganisms were isolated from cultural heritage artefacts. Reviewing all the available data is, hence, of pivotal importance and we hope, as participants of this initiative, to ease the way into the world of paper biodeterioration by fungal agents.

\section{Disclosure statement}

No potential conflict of interest was reported by the authors.

\section{Funding}

This work was supported with Portuguese funds by FCT Fundação para a Ciência e Tecnologia, I.P., under grants SFRH/BD/36005/2007 and SFRH/BD/72216/2010, under the framework of research project PTDC/EPH-PAT/0224/2014 and VICARTE Research Unit (UID/EAT/00729/2013), and by FEDER - Fundo Europeu de Desenvolvimento Regional funds through the COMPETE 2020 - Operational Programme for Competitiveness and Internationalization (POCI), in the framework of the project POCI-01-0145-FEDER-PTDC/EPHPAT/3345/2014. 


\section{ORCID}

Ana Catarina Pinheiro (iD) http://orcid.org/0000-00027194-5496

Sílvia Oliveira Sequeira (iD http://orcid.org/0000-00024882-7133

Maria Filomena Macedo iD http://orcid.org/0000-00034366-4192

\section{References}

Abdel-Azeem AM, Gherbawy YA, Sabry AM. 2016. Enzyme profiles and genotyping of Chaetomium globosum isolates from various substrates. Plant Biosyst. 150(3):420-428.

Abrusci C, Martín-González A, Del Amo A, Catalina F, Collado J, Platas G. 2005. Isolation and identification of bacteria and fungi from cinematographic films. Int Biodeterior Biodegr. 56(1):58-68.

Adamo M, Magaudda G, Nisini PT, Tronelli G. 2003. Susceptibility of cellulose to attack by cellulolytic microfungi after gamma irradiation and ageing. Restaurator. 24: 145-151.

Adan OCG, Samson RA, editors. 2011. Fundamentals of mold growth in indoor environments and strategies for healthy living. Wageningen, The Netherlands: Wageningen Academic.

Adelantado C, Bello C, Borrell A, Calvo MA. 2005. Evaluation of the antifungal activity of products used for disinfecting documents on paper in archives. Restaurator. 26:235-238.

Anaya M, Borrego SF, Gámez E, Castro M, Molina A, Valdés O. 2016. Viable fungi in the air of indoor environments of the National Archive of the Republic of Cuba. Aerobiologia. 32(3):513-527.

Andersen B, Poulsen R, Hansen GH. 2016. Cellulolytic and xylanolytic activities of common indoor fungi. Int Biodeterior Biodegra. 107:111-116.

Bankole OM. 2010. A review of biological deterioration of library materials and possible control strategies in the tropics. Libr Rev. 59(6):414-429.

Bennett JW, Klich M. 2003. Mycotoxins. Clin Microbiol Rev. 16(3):497-516.

Bergadi F, Laachari F, Elabed S, Mohammed IH, Ibnsouda SK. 2014. Cellulolytic potential and filter paper activity of fungi isolated from ancients manuscripts from the Medina of Fez. Ann Microbiol. 64:815-822.

Di Bonaventura MP, DeSalle R, Eveleigh DE, Baldwin A, Koestler RJ. 2003. Studies of fungal infestations of Tiffany's Drawings: limits and advantages of classical and molecular techniques. In: Koestler RJ, Koestler VH, Charola AE, NietoFernández $\mathrm{FE}$, editors. Art, Biology, and Conservation: Biodeterioration of Works of Art. New York (NY): The Metropolitan Museum of Art; p. 94-109.

Borrego S, Lavin P, Perdomo I, Gómez de Saravia S, Guiamet P. 2012. Determination of indoor air quality in archives and biodeterioration of the documentary heritage. ISRN Microbiol. 2012:1-10.

Brokerhof AW, van Zanen B, den Teuling A. 2007. Fluffy stuff - integrated control of mould in archives. Amsterdam, The Netherlands: Netherlands Institute for Cultural Heritage (ICN).

Caneva G, Maggi O, Nugari MP, Pietrini AM, Piervittori R, Ricci S, Roc-Cardi A. 2003. The biological aerosol as a factor of biodeterioration. In: Mandrioli P, Caneva G, Sabbioni $C$, editors. Cult herit aerobiol - methods meas tech biodeterior monit. Dordrecht, The Netherlands: Kluwer Academic Publishers; p. 3-29.

Canhoto O, Pinzari F, Fanelli C, Magan N. 2004. Application of electronic nose technology for the detection of fungal contamination in library paper. Int Biodeterior Biodegr. 54(4):303-309.

Capderou C, Flieder F. 1999. Sauvegarde des collections du patrimoine: la lute contre les détériorations biologiques. Paris: CNRS éditions.

Cappitelli F, Fermo P, Vecchi R, Piazzalunga A, Valli G, Zanardini E, Sorlini C. 2009. Chemical-physical and microbiological measurements for indoor air quality assessment at the Ca' granda historical archive, Milan (Italy). Water Air Soil Pollut. 201(1-4):109-120.

Cappitelli F, Pasquariello G, Tarsitani G, Sorlini C. 2010. Scripta manent? Assessing microbial risk to paper heritage. Trends Microbiol. 18(12):538-542.

Castillo NI, Ibáñez M, Beltrán E, Rivera-Monroy J, Ochoa JC, Páez-Castillo M, Posada-Buitrago ML, Sulyok M, Hernndez F. 2016. Identification of mycotoxins by UHPLC-QTOF MS in airborne fungi and fungi isolated from industrial paper and antique documents from the Archive of Bogotá. Environ Res. 144:130-138.

Chang YC, Tsai HF, Karos M, Kwon-Chung KJ. 2004. THTA, a thermotolerance gene of Aspergillus fumigatus. Fungal Genet Biol. 41(9):888-896.

Chinedu SN, Okochi VI, Omidiji O. 2011. Cellulase production by wild strains of Aspergillus niger, Penicillium chrysogenum and Trichoderma harzianum grown on waste cellulosic materials. IFE J Sci. 13:57-62.

Coronado-Ruiz C, Avendaño R, Escudero-Leyva E, Conejo-Barboza G, Chaverri P, Chavarría M. 2018. Two new cellulolytic fungal species isolated from a 19th-century art collection. Sci Rep. 8(1):1-9.

Corte AM, Ferroni A, Salvo VS. 2003. Isolation of fungal species from test samples and maps damaged by foxing, and correlation between these species and the environment. Int Biodeterior Biodegradation. 51(3):167-173.

Das MKL, Prasad JS, Ahmad SK. 1997. Endoglucanase production by paper-degrading mycoflora. Lett Appl Microbiol. 25(5):313-315.

Duchaine C, Mériaux A. 2001. The importance of combining air sampling and surface analysis when studying problematic houses for mold biodiversity determination. Aerobiologia. 17(2):121-125.

Etkin DS. 1994. Particulates in the indoor environment: characterisation and health effects. Arlington (MA): Cutter Information Corp.

Fabbri AA, Ricelli A, Brasini S, Fanelli C. 1997. Effect of different antifungals on the control of paper biodeterioration caused by fungi. Int Biodeterior Biodegr. 39(1):61-65.

Fávaro Lc de L, de Melo FL, Aguilar-Vildoso Cl, Araújo WL. 2011. Polyphasic analysis of intraspecific diversity in Epicoccum nigrum warrants reclassification into separate species. PLoS One. 6:e14828.

Flannigan B, Samson RA, Miller JD, editors. 2011. Microorganisms in home and indoor work environments diversity. Health impacts, investigation and control. 2nd ed. Boca Raton (FL): CRC Press, Taylor \& Francis Group. 
Florenzano G. 1949. Studi sul genere chaetomium: 2. Inquadramento fisiologico e proprietà cellulosolitiche delle diverse specie di chaetomium. Boll Ist Patol. 8:61-74.

Florian MLE, Manning L. 2000. SEM analysis of irregular fungal fox spots in an 1854 book: population dynamics and species identification. Int Biodeterior Biodegr. 46(3): 205-220.

Fogarty WM, Kelly CT. 1979. Amylases, amyloglucosidases and related glucanases. In: Rose $\mathrm{AH}$, editor. Economic microbiology. Vol. 5. London: Academic Press Inc. Ltd.; p. $115-170$.

Gopinath SCB, Anbu P, Hilda A. 2005. Extracellular enzymatic activity profiles in fungi isolated from oil-rich environments. Mycoscience. 46(2):119-126.

Goyer N, Lavoie J, Lazure L. 2001. Bioaerosols in the workplace: evaluation, control and prevention guide. Québec: IRSST.

Harkawy A, Górny RL, Ogierman L, Wlazło A, ŁawniczekWałczyk A, Niesler A. 2011. Bioaerosol assessment in naturally ventilated historical library building with restricted personnel access. Ann Agric Environ Med. 18(2):323-329.

Hayleeyesus SF, Manaye AM. 2014. Microbiological quality of indoor air in university libraries. Asian Pac J Trop Biomed. 4:S312-S317.

Hurts C, Walter M, Stetzenbach L. 1997. Manual of environmental microbiology. Washington (DC): ASM Press.

Hyvärinen A, Meklin T, Vepsalainen A, Nevalainen A. 2002. Fungi and actinobacteria in moisture-damaged building materials - concentrations and diversity. Int Biodeterior Biodegr. 49:27-37.

Jain AK. 2000. Survey of bioaerosol in different indoor working environments in central India. Aerobiologia (Bologna). 16(2):221-225.

Janda K, Ulfig K, Markowska-Szczupak A. 2009. Further studies of extracellular enzyme profiles of xerophilic fungi isolates from dried medicinal plants. Polish J Environ Stud. 18:627-633.

Jorgensen TR, Park J, Arentshorst $M$, van Welzen AM, Lamers G, VanKuyk PA, Damveld RA, van den Hondel CAM, Nielsen KF, Frisvad JC. 2011. The molecular and genetic basis of conidial pigmentation in Aspergillus niger. Fungal Genet Biol. 48:544-553.

Karakasidou K, Nikolouli K, Amoutzias GD, Pournou A, Manassis C, Tsiamis G, Mossialos D. 2018. Microbial diversity in biodeteriorated Greek historical documents dating back to the 19th and 20th century: a case study. Microbiologyopen. 7:e00596.

Karbowska-Berent J, Górny RL, Strzelczyk AB, Wlazło A. 2011. Microbial quality in selected Polish libraries and archives. Build Environ. 46(10):1872-1879.

Khan AAH, Karuppayil SM, Manoharachary C, Kunwar IK, Waghray S. 2009. Isolation, identification and testing for allergenicity of fungi from air-conditioned indoor environments. Aerobiologia (Bologna). 25(2):119-123.

Khan H, Karuppayil M. 2012. Fungal pollution of indoor environments and its management. Saudi J Biol Sci. 19: 405-426.

Klánová K. 2000. The concentrations of mixed populations of fungi in indoor air: rooms with and without mould problems, rooms with and without health complaints. Cent Eur J Public Health. 8(1):59-61.
Kolstad HA, Brauer C, Iversen M, Sigsgaard T, Mikkelsen S. 2002. Do indoor moulds in nonindustrial environments threaten workers' health? A review of the epidemiologic evidence. Epidemiol Rev. 24(2):203-217.

Kraková L, Chovanová K, Selim S. A, Šimonovičová A, Puškarová A, Maková A, Pangallo D. 2012. A multiphasic approach for investigation of the microbial diversity and its biodegradative abilities in historical paper and parchment documents. Int Biodeterior Biodegr. 70:117-125.

Kraková L, Šoltys K, Otlewska A, Pietrzak K, Purkrtová S, Savická D, Puškárová A, Bučková M, Szemes T, Budiš J, et al. 2018. Comparison of methods for identification of microbial communities in book collections: culturedependent (sequencing and MALDI-TOF MS) and cultureindependent (Illumina MiSeq). Int Biodeterior Biodegr. 131: 51-59.

Lakshmikant. 1990. Cellulose degradation and cellulase activity of five cellulolytic fungi. World J Microbiol Biotechnol. 6:64-66.

Lignell $U$, Meklin T, Rintala $H$, Hyvärinen A, Vepsäläinen A, Pekkanen J, Nevalainen A. 2008. Evaluation of quantitative PCR and culture methods for detection of house dust fungi and streptomycetes in relation to moisture damage of the house. Lett Appl Microbiol. 47(4):303-308.

Lourenço MJL, Pol LV, Sampaio JP, Philips A, Fonseca A, Vieira J. 2005. Isolamento, identificação e caracterização de microrganismos contaminantes dos arquivos da Direcção Geral dos Edifícios e Monumentos Nacionais. A história, a formação e as boas práticas em conserv e restauro. Lisbon: Atas do $4^{\circ}$ Encontro do Instituto Português de Conservação e Restauro.

Low SY, Dannemiller K, Yao M, Yamamoto N, Peccia J. 2011. The allergenicity of Aspergillus fumigatus conidia is influenced by growth temperature. Fungal Biol. 115(7): 625-632.

Lugauskas A, Krikŝtaponis A. 2004. Microscopic fungi found in the libraries of vilnius and factors affecting their development. Indoor Built Environ. 13(3):169-182.

Maggi O, Persiani AM, Gallo F, Valenti P, Pasquariello G, Sclocchi MC, Scorrano M. 2000. Airborne fungal spores in dust present in archives: proposal for a detection method, new for archival materials. Aerobiologia (Bologna). 16(3-4): 429-434.

Mesquita N, Portugal A, Videira S, Rodriguez-Echeverria S, Bandeira AML, Santos MJA, Freitas H. 2009. Fungal diversity in ancient documents. A case study on the Archive of the University of Coimbra. Int Biodeterior Biodegr. 63(5): 626-629.

Messner K, Alberighi L, Banik G, Srebotnik E, Sobotka W, Mairinger A. 1988. Comparison of possible chemical and microbial factors influencing paper decay by iron-gall inks. In: Houghton DR, Smith RN, Eggins HOW, editors. Biodeterior 7 sel pap present seventh international biodeterioration symposium. Cambridge, UK, 6-11 Sept 1987. Cambridge: Elsevier Science Publishers, Ltd.; p. 449-454.

MIBAC (Italian Ministry of Cultural Heritage). 2001. Atto di indirizzo sui criteri tecnico-scientifi ci e sugli standard di funzionamento e sviluppo dei musei, Ambito VI. D.Lgs. 112/1998 (art. 150, comma 6). p. 81-94.

Micalli O, Montacutelli R, Tarsitani G. 2003. Pathogenic microorganisms and situations of risk to man. In: Mandrioli $P$, Caneva G, Sabbioni C, editors. Cult herit aerobiol - 
methods meas technic biodeterior monitor. Dordrecht, The Netherlands: Kluwer Academic Publishers; p. 31-43.

Michaelsen A, Pinar G, Montanari M, Pinzari F. 2009. Biodeterioration and restoration of a 16th-century book using a combination of conventional and molecular techniques: a case study. Int Biodeterior Biodegr. 63(2): 161-168.

Michaelsen A, Piñar G, Pinzari F. 2010. Molecular and microscopical investigation of the microflora inhabiting a deteriorated Italian manuscript dated from the thirteenth century. Microb Ecol. 60(1):69-80.

Molina-Veloso A, Borrego-Alonso SF. 2017. Viable allergenic fungi in a documentary deposit of the National Archive of Cuba. Rev Alerg Mex. 64(1):40-51.

Nevailanen A, Hyvarynen A. 2015. Fungi in low-contamination occupational environments. In: Viegas $P$, Viegas $S$, Veríssimo $B$, editors. Public heal fungi mycotoxins risk assess manage. Amsterdam, The Netherlands: Elsevier Science Publishing Company Incorporated; p. 107-124.

Nielsen KF. 2003. Mycotoxin production by indoor molds. Fungal Genet Biol. 39:103-117.

Nol L, Henis Y, Kenneth RG. 2001. Biological factors of foxing in postage stamp paper. Int Biodeterior Biodegr. 48(1-4): 98-104.

NT-SCE-02. 2009. Nota Técnica - NT -SCE - $02-$ Metodologia para auditorias periódicas de QAI em edifícios existentes no Âmbito do RSECE [Technical note NT-SCE-02- Methodology for periodic IAQ audits of existing buildings within the RSECE (Regulation of Energy Conditioning Systems in Buildings)]. Lisbon.

Oetari A, Susetyo-Salim T, Sjamsuridzal W, Suherman EA, Monica M, Wongso R, Fitri R, Nurlaili DG, Ayu DC, Teja TP. 2016. Occurrence of fungi on deteriorated old dluwang manuscripts from Indonesia. Int Biodeterior Biodegr. 114: 94-103.

Ohgke H, Geers A, Beckert J. 1987. Fungal load of indoor air in historical and newly constructed buildings used by public services. In: Seifkrt B, Worn H, Fischer M, Ruden $H$, Wegner $\mathrm{J}$, editors. Proceedings of the 4th International Conference on Indoor Air Quality and Climate. Berlin (West): Institute of Water, Soil and Air Hygiene; p. 681-684.

Okpalanozie OE, Adebusoye SA, Troiano F, Cattò C, llori MO, Cappitelli F. 2018. Assessment of indoor air environment of a Nigerian museum library and its biodeteriorated books using culture-dependent and - independent techniques. Int Biodeterior Biodegr. 132:139-149.

Oyeleke SB, Egwim EC, Auta SH. 2010. Screening of Aspergillus flavus and Aspergillus fumigatus strains for extracellular protease enzyme production. J Microbiol Antimicrob. 2:83-87.

Pandey S, Srivastava M, Shahid M, Kumar V, Singh A, Trivedi S, Srivastava YK. 2015. Trichoderma species cellulases produced by solid state fermentation. J Data Mining Genomics Proteomics. 06:2-5.

Parchas M. 2009. Comment faire face aux risques biologiques? Paris: Direction des Archives de France.

Parra R, Magan N. 2004. Modelling the effect of temperature and water activity on growth of Aspergillus niger strains and applications for food spoilage moulds. J Appl Microbiol. 97(2):429-438.
Pasanen AL, Kalliokoski P, Pasanen $\mathrm{P}$, Jantunen MJ, Nevalainen A. 1991. Laboratory studies on the relationship between fungal growth and atmospheric temperature and humidity. Environ Int. 17(4):225-228.

Pietrzak K, Otlewska A, Danielewicz D, Dybka K, Pangallo D, Kraková L, Puškárová A, Bučková $M$, Scholtz V, Durovič $M$, et al. 2017. Disinfection of archival documents using thyme essential oil, silver nanoparticles misting and low temperature plasma. J Cult Herit. 24:69-77.

Pinheiro AC. 2015. Fungi in archives: a double concern. In: Viegas P, Sabino V, Brandão V, editors. Environ mycol public heal fungi mycotoxins risk assess manage. Oxford: Academic Press; p. 157-166.

Pinheiro AC. 2014. Fungal communities in archives: assessment strategies and impact on paper conservation and human health. [dissertation]. Lisbon, Portugal: Universidade Nova de Lisboa.

Pinzari F, Pasquariello G, De Mico A. 2006. Biodeterioration of paper: a SEM study of fungal spoilage reproduced under controlled conditions. Macromol Symp. 238(1):57-66.

Pinzari F, Zotti M, De Mico A, Calvini P. 2010. Biodegradation of inorganic components in paper documents: formation of calcium oxalate crystals as a consequence of Aspergillus terreus Thom growth. Int Biodeterior Biodegr. 64(6): 499-505.

Pitt Jl, Hocking AD. 2009. Fungi and food spoilage. 3rd ed. In: Hocking AD, Pitt Jl, Samson RA, Thrane U, editors. New York (NY): Springer.

Ponce-Jimenez MD, Toral F, Fornue ED. 2002. Antifungal protection and sizing of paper with chitosan salts and cellulose ethers. Part 1, physical effects. J Am Inst Conserv. 41: 243-254.

Rakotonirainy MS, Heude E, Lavédrine B. 2007. Isolation and attempts of biomolecular characterization of fungal strains associated to foxing on a 19th century book. J Cult Herit. 8(2):126-133.

Reiss J. 1978. Mycotoxins in foodstuffs - XII. The influence of the water activity (alpha-omega) of cakes on the growth of molds and the formation of mycotoxins. Zeitschrift Fur Leb Und-Forsch. 167:419-422.

Reynolds SJ, Streifel AJ, Mcjilton CE. 1990. Elevated airborne concentrations of fungi in residential and office environment. Am Ind Hyg Assoc J. 51(11):601-604.

Ricelli A, Fabbri AA, Fanelli C, Menicagli R, Samaritani S, Pini D, Rapaccini SM, Salvadori P. 1999. Fungal growth on samples of paper: inhibition by new antifungals. Restaurator. 20:97-107.

Ruegger MJS, Tauk-Tornisielo SM. 2004. Atividade da celulase de fungos isolados do solo da estação ecológica de Juréia-Itatins, São Paulo, Brasil. Rev Bras Bot. 27(2): 205-211.

Saleem A, Ebrahim M. 2014. Production of amylase by fungi isolated from legume seeds collected in Almadinah Almunawwarah, Saudi Arabia. J Taibah Univ Sci. 8(2): 90-97.

Samson RA, Hoekstra ES, Frisvad JC, Filtenborg O, editors. 2000. Introduction to food and airborne fungi. 6th ed. Utrecht, The Netherlands: Centraalbureau Voor Schimmelculture.

Samson RA, Hoekstra ES, Frisvad JC, Filtenborg O. 2010. Introduction to food-and airborne fungi. 7th ed. Utrecht: Centraalbureau Voor Schimmelculture. 
Sato Y, Aoki M, Kigawa R. 2014. Microbial deterioration of tsunami-affected paper-based objects: a case study. Int Biodeterior Biodegr. 88:142-149.

Sautour M, Soares Mansur C, Divies C, Bensoussan $M$, Dantigny P. 2002. Comparison of the effects of temperature and water activity on growth rate of food spoilage moulds. J Ind Microbiol Biotech. 28(6):311-315.

Sequeira SO, Carvalho H. D, Mesquita N, Portugal A, Macedo MF. 2019. Fungal stains on paper: is what you see what you get? Conserv património. 32:18-27.

Sequeira SO, Phillips AJL, Cabrita EJ, Macedo MF. 2017. Antifungal treatment of paper with calcium propionate and parabens: Short-term and long-term effects. Int Biodeterior Biodegradation. 120:203-215.

Shahriarinour M, Noor M, Wahab A, Mohamad R, Mustafa S, Ariff AB. 2011. Effect of medium composition and cultural condition on cellulase production by Aspergillus terreus. Afr J Biotechnol. 10:7459-7467.

Sharma D, Shukla AK. 2008. Starch hydrolysis and alphaamylase activity of Aspergillus and Chaetomium. Asian J Biochem. 3:284-289.

da Silva M, Moraes AML, Nishikawa MM, Gatti MJA, Vallim de Alencar MA, Brandao LE, Nobrega A. 2006. Inactivation of fungi from deteriorated paper materials by radiation. Int Biodeterior Biodegr. 57(3):163-167.

Skeist I 2007. Handbook of adhesives. Vol. 104. Chapman \& Hall. http://doi.org/10.1073/pnas.0703993104.

Sterflinger K. 2010. Fungi: their role in deterioration of cultural heritage. Fungal Biol Rev. 24(1-2):47-55.

Sterflinger K, Engel P. 2014. Microorganisms in books - the archives of the protestant Parish of the holy trinity in Swidnica. St. Pölten, Austria: Men Books From Microorg to Megaorganisms. Poster resentation.

Sterflinger K, Little B, Pinar G, Pinzari F, de los Rios A, Gu JD. 2018. Future directions and challenges in biodeterioration research on historic materials and cultural properties. Int Biodeterior Biodegr. 129:10-12.

Szczepanowska H, Cavaliere A. 2000. Fungal deterioration of 18th and 19th century documents: a case study of the Tilghman Family Collection, Wye House, Easton, Maryland. Int Biodeterior Biodegr. 46(3):245-249.

Szczepanowska HM, Cavaliere AR. 2003. Artworks, drawings, prints, and documents fungi eat them all! In: Koestler RJ, Koestler VH, Charola AE, Nieto-Fernandez F, editors. Art, biology, and conservation: biodeterioration of works of art. New York (NY): The Metropolitan Museum of Art; p. 128-151.

Teixeira FS, dos Reis TA, Sgubin L, Thomé LE, Bei IW, Clemencio RE, Corrêa B, Salvadori MC. 2018. Disinfection of ancient paper contaminated with fungi using supercritical carbon dioxide. J Cult Herit. 30:110-116.

Tepsic K, Gunde-Cimerman N, Frisvad JC. 1997. Growth and mycotoxin production by Aspergillus fumigatus strains isolated from a saltern. Fems Microbiol Lett. 157:9-12.

Valentin N. 2007. Microbial contamination in archives and museums: health hazards and preventive strategies using air ventilation systems. In: Boersma F, editor. Experts' roundtable on sustainable climate management strategies. Tenerife, Spain: The Getty Conservation Institute; p. 1-26.

Valentin N. 2010. Microorganisms in museum collections. Coalition. 19:2-5.

Viegas C, Almeida-Silva M, Gomes A. Q, Wolterbeek HT, Almeida SM. 2014. Fungal contamination assessment in Portuguese elderly care centers. J Toxicol Environ Heal Part A. 77(1-3):14-23.

Viegas C, Alves C, Carolino E, Pinheiro C, Rosado L, SilvaSantos C. 2011. Assessment of fungal contamination in a group of Lisbon's gymnasiums with a swimming pool. Ital J Occup Environ Hyg. 2:15-20.

Wiszniewska M, Walusiak-Skorupa J, Pannenko I, Draniak M, Palczynski C. 2009. Occupational exposure and sensitization to fungi among museum workers. Occup Med (Lond). 59(4):237-242.

Yang CS, Hung LL, Lewis FA, Zampiello FA. 1993. Airborne fungal populations in non-residential buildings in the United States. In: Seppänen O, editor. Indoor Air Part Microbes, Radon Proceedings Sixth International Conference Indoor Air Quality Climate. Helsinki, Finland: Helsinki University of Technology; p. 219-224.

Zerek BF. 2003. Fungi isolated from paper works of art identification, susceptibility to the chosen methods used in the conservation of paper, susceptibility of the chosen kinds of paper to infections. Warszawa, Poland: University of Warsaw.

Zielinska-Jankiewicz K, Kozajda A, Piotrowska M, SzadkowskaStanczyk I. 2008. Microbiological contamination with moulds in work environment. Ann Agric Environ Med. 15(1):71-78.

Zotti M, Ferroni A, Calvini P. 2007. Inhibition properties of simple fungistatic compounds on fungi isolated from foxing spots. Restaurator. 28:201-217.

Zotti M, Ferroni A, Calvini P. 2008. Microfungal biodeterioration of historic paper: preliminary FTIR and microbiological analyses. Int Biodeterior Biodegr. 62(2):186-194.

Zyska B. 1997. Fungi isolated from library materials: a review of the literature. Int Biodeterior Biodegr. 40(1):43-51.

Zyska BJ. 2002. Problems of microbial deterioration of materials in Eastern Europe. Int Biodeterior Biodegr. 49(1): 73-83. 